\title{
E-Supplier Management Practices on SupPly Chain Performance of Sugar Processing Firms in KenYa
}

\author{
Evans Biraori Oteki \\ Lecturer, Murang'a University of Technology, Kenya
}

\begin{abstract}
The purpose of this study was to establish the influence of electronic supplier management practices on supply chain performance of sugar processing firms. The target population is 7,584 employees of sugar processing firms in Kenya and Yamane Taro's formula was applied to come up with a sample size of 379 respondents. Data was gathered by a questionnaire, interviews and observation. Correlation was used to determine the relationship between E-supplier management practices and Supply chain performance while regression analysis tested the hypothesis. The study established that E-supplier management practices enhances supply chain performance. Two kinds of supply chain are proposed; Managerial and demand. Managerial supply chain where as a result of electronic supplier management practice, flow of goods and services from the suppliers are properly managed through information sharing between the buyer-seller thus improved deliveries. Demand supply chain where as a result of electronic supplier management practice, buyers and suppliers tend to develop a single shared forecast of demand and a plan of supply in the sense that buyers issue order for only needed materials from the suppliers and that suppliers fulfills the orders as requested by the buyers. To ensure that the proposed supply chain under e-supplier management, it is recommended that Sugar processing firms' management should ensure working Websites, working internal and external mail and also provide their suppliers with access credentials to company electronic procurement portal to increase buyer and supplier access to information to enhance E-supplier management practices.
\end{abstract}

\section{KEYWORDS}

Electronic supplier management, sugar processing firms, Supply chain performance.

\section{INTRODUCTION}

A good e-procurement system must have all elements that enable the buyers and sellers interact effectively including all supply chain activities from procurement planning information to supplier evaluation. Both buyers and sellers should have access to each other's information as and when required electronically for smooth functioning of E-procurement. The commonly adopted e-procurement practices used in procurement includes: E-Tendering, E-Request for Quotations, E-Auctions, E-Catalogues, and E-Invoicing [1]. According to Mc Cue and Roma [2], tools such as E-Notice, E-Auction, E-Catalogue, E-Dossier, E-Submission and E-Signatures are part and parcel of e-procurement. Others also considered in this study include; Enterprise Resource planning (ERP); an information system package that integrates information and processes across organizational functions [3], E-maintenance; maintenance managed through computer over the internet [4], E-tendering, tendering through online platforms and E-Sourcing (online sourcing).

According to Jessop, using Internet technology to buy goods and services from a number of known or unknown suppliers improved the vendor process in Australia with much improvement 
being realized on the part of, e-informing: Gathering and distributing purchasing information both from and to internal and external parties using Internet technology, e-market sites: Expands on Web-based ERP to open up value chains. Buying communities can access preferred suppliers' products and services, add to shopping carts, create requisition, and seek approval, receipt purchase orders and process electronic invoices with integration to suppliers' supply chains and buyers' financial systems [5].

The intensity of supplier-buyer interaction has been further enhanced by the diffusion of eProcurement systems in the late 1990s has created the potential for reorganizing the MRO supply chains. Compared to ERP, these systems were considerably less expensive and more flexible due to increased standardization on a technical level. The current phase of development in eprocurement has been observable with the integration of electronic markets (e-Markets) in the supply chain since the end of the 1990s [6]. These e-Markets evolved alongside the early system vendors like Ariba, Commerce One or SAP and support the outsourcing of operational procurement functions, offering tools for auctions and requests for quotations. However, following the evolution of e-Markets has led to a substantial consolidation and many now focus on outsourced solutions for catalogs and auctions.

In Kenya, there are some organizations that have successfully embraced the use of e-procurement technology. For instance Nation Media group through their digital platform commonly known as $\mathrm{N}$-Soko enables their clients to purchase products online [7]. Many platforms also offer access over smart phones and tablets such as Mpesa ervice where goods and services are paid for electronically by use of pay bill or till number on the Safaricom platform in Kenya. This has greatly improved buyer-supplier by easing out payment period.

The Kenyan government launched an online system for submitting and evaluating procurement applications in a bid to become more efficient and eliminate corruption. Subsequently the goal is also to slash long queues and processes that take time. As part of the 'Integrated Financial Management Information System' (IFMIS) under the national treasury, the system is intended to give applicants clear instructions and guidelines on how to apply for Government tenders. The system was expected to reduce government spending by having a level playing field for all, [8].

\subsection{Statement of the Problem}

The application of manual procurement processes to procure goods, services or works is a challenge for sugar manufacturing firms in acquiring such goods, services or works at the right time, price, place, quantity and quality. As per Kenya National assembly, luck of efficiency and effectiveness of procurement process, the government of Kenya continues to lose millions of shillings through fraud in procurement activities in the government mainstream [9]. The Kenya Sugar Directorate noted that sugar industry in Kenya is currently faced with grave problems that include high costs of inputs and stiff competition from low cost manufacturers. Based on supply and demand for the products, it's clear that significant changes and investigation on increasing the performance and competitiveness of this segment is still a key national priority. Kenya Sugar segment is destined to undertake key reforms in several aspects to build competitiveness and introduce effective governance in the commodity supply chain [10].

\subsection{Objective of the Study}

To find out the influence of electronic supplier management practice on supply chain performance of sugar processing firms in Kenya. 
International Journal of Managing Value and Supply Chains (IJMVSC) Vol. 12, No. 2, June 2021

\subsection{Research Hypothesis}

Ho: Electronic supplier management practices have no significant positive influence on supply chain performance of sugar processing firms in Kenya.

\section{LiteratURE REVIEW}

\subsection{Theoretical Framework}

From the theoretical framework, Electronic supplier management practices are explained by the Resource Based View Theory. [11] asserts that supply chain integration links an organization with its customers, suppliers and other channel members by integrating their relationships, activities functions, processes and locations. Successful supply chain management requires crossfunctional integration of key business processes within the company and across the network of companies that consist of the supply chain. Organizations must integrate their operations with trading partners in order to sustain competitive advantage for the whole supply chain.

\subsubsection{Resource Based View Theory}

The Resource Based View (RBV) theory was developed by Barney and Wernerfelt in 1930s in their analysis of heterogeneous firms which introduced the idea of resource position barriers being roughly analogous to entry barriers. It asserts that the resources of an organization are key to ensuring that it performs well. These resources are what determines if an organization has an added advantage over the rest. As a result, exploiting surrounding opportunities using available resources in a new way is more efficient rather than acquiring new skills for each different opportunity. According to the RVB theory, resources can be classified into organizational capital resources, physical capital resources and human capital resources. Allocating them efficiently helps an organization to achieve greater performance [12].

The RBV can be used as a basis for the development of supply chain strategy taxonomy [13]. SCI requires a collaborative effort between a manufacturer and its suppliers and customers [14]. If a firm is completely vertically integrated, most of the prominent materials supplies are provided by its internal units. In fact, firms also acquire external resources from external parties such as suppliers and customers. [15] highlighted that valuable resources are often provided by supply chain partners and argued that structuring the inter-organisational resources is more critical to achieve outstanding performance than a firm's own constrained resource base. Specifically, suppliers play an integral role in supplying essential resources to the focal firm as well as in the firm's implementation strategies. Accordingly, the external resources must be effectively managed and integrated with the internal resources of the firm in order to achieve superior performance [16]. The heterogeneous partner-specific resources therefore constitute the potential for a competitive advantage. Moreover, the sustainability of the competitive advantage can be achieved when the resources are immobile and difficult to imitate or appropriate. The RBV suggests that holding valuable, rare, inimitable and non-substitutable resources is important, however, it is more important for a firm to leverage and bundle its internal and external resources in order to create its competitive advantage.

Integration is a process of interaction and collaboration in which companies in a supply chain work together in a cooperative manner to achieve mutually acceptable outcomes [17] asserts that supply chain integration links an organization with its customers, suppliers and other channel members by integrating their relationships, activities functions, processes and locations. According to [18], successful supply chain management requires cross-functional integration of 
International Journal of Managing Value and Supply Chains (IJMVSC) Vol. 12, No. 2, June 2021

key business processes within the company and across the network of companies that consist of the supply chain. Organizations must integrate their operations with trading partners in order to sustain competitive advantage for the whole supply chain [19]. [20] asserts that integration involves the cooperation, collaboration, information sharing, trust, partnerships, shared technology and a fundamental shift away from managing individual functional processes to managing integrated chains of processes. [21] Consider supply chain integration to be a strategic tool that aims to reduce costs and thus increase customer and shareholder value. Supply chain integration is a good approach for improving business performance in a highly competitive market [22]. [23] assert that the highest levels of integration with both suppliers and customers have the highest correlation with high levels of an organization's performance.

The major challenge in supply chain integration is to coordinate activities across the supply chain so that the enterprise can improve performance by reducing costs, increasing service levels, reducing the bullwhip effect, better utilization of resources and effectively responding to changes in the market place [24]. [25] argues that supply chain coordination occurs when all the different stages of supply chain work toward the objective of maximizing total supply chain profitability rather than each stage devoting itself to its own profitability.

\subsection{Conceptual Framework}

For clearly understanding of this study variables, the researcher presents in figure form the conceptualized relationship between variables. In this study, the independent variable conceptualized as having influence on the performance of supply chain is electronic supplier management practices. According to [26], effective supply management and its strategies for creating competitiveness revolve around the on-time delivery of competitive quality goods and services, at a reasonable cost, involving the right business partners.

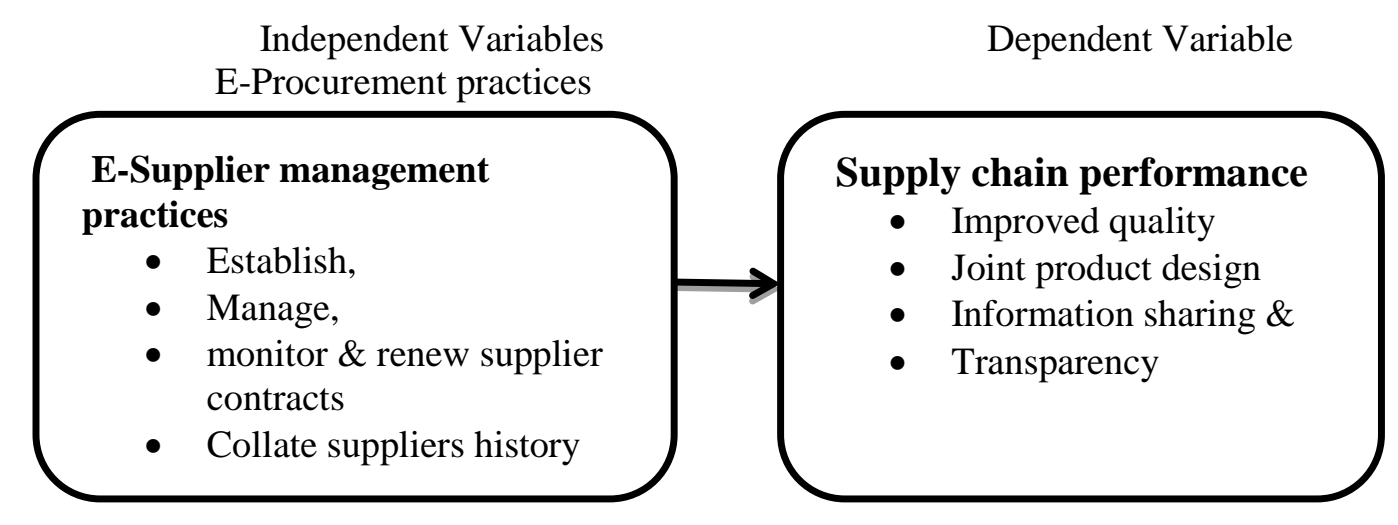

Figure 1.1 Conceptual Framework

\subsubsection{Electronic Supplier Management Practice}

E-Supplier Management involves use of ICT to make informed decisions on sourcing the right suppliers by modules on Self-service supplier portal, standardized supplier qualification, Customized vendor registration forms, Centralized visibility of supplier data, Track supplier performance (KPIs), Promote supplier diversity, and Manage insurance certificates. Efficiently engage suppliers for sourcing events, analyze supplier responses, and make smart award decisions by use of modules such as Electronic bidding, Bid tabulation, Supplier response scoring, Efficient bid document distribution, RFI/RFP/RFQ templates, Sealed bidding, Reverse and forward auction and Audit trail of transactions, Contract Management by Proactively 
managing supplier engagements to mitigate risk and ensure compliance by use Centralized supplier contract data, Custom contract fields, Contract document management, Subcontract visibility, Expiration alerts, Invoicing and payment tracking and compliance reporting. Telecommunications and computer technology allow all the actors in the supply chain to communicate among each other. The use of information technology allows suppliers, manufacturers, distributors, retailers, and customers to reduce lead time, paperwork, and other unnecessary activities. It is also mentioned that managers will experience considerable advantages with its use such as the flow of information in a coordinated manner, access to information and data interchange, improved customer and supplier relationships, and inventory management not only at the national level but also internationally. Also the advantages will include supply contracts via internet, distribution of strategies, outsourcing and procurement [27]. All companies are looking for cost and lead time reductions with the purpose of improving the level of service but also to enhance inter-organizational relationships [28].

Tim [29] states that through the use of communication tools, such as the web sites, industrial organizations can build value in their supply chain relationships. [30] indicates that firms cannot effectively manage cost, offer high customer service, and become leaders in supply chain management without the incorporation of top of- the-line information technologies. [31] identified 14 such information technology tools, among them electronic data interchange (EDI), enterprise resource planning (ERP), internet and extranets. Li grouped these tools into three groups in terms of their primary purpose: communication tools, resource planning tools, and supply chain management tools. Given this classification, two sub factors are considered in this research: Communication tools are used to facilitate data transfer and communication between the trading parts and this might include EDI, electronic fund transfer (EFT), intranet, internet, and extranet [32]. Electronic Data Interchange (EDI) is used for procurement (purchase orders, order status, and order follow-up). EDI serves as electronic catalogs for customers who can get information, dimensions, and cost about a specific product. EFT provides trading partners with an effective way to transfer funds from one account to another through a value added network (VAN) or the internet. Intranets are corporate local area networks (LAN) or wide area networks (WAN) that communicate through the internet and are secured by firewalls. Usually this type of communication tool is used inside a corporation that features different locations. On the other hand, extranet allows business to communicate and share business with external collaborators with a certain degree of security and privacy. Another type of communication tool is the internet, a uniform interface that allows global communication with the use of browsers [33].

Manufacturing firms depend to a larger extent on their suppliers to avail the right products, in the right quality, quantity and in the right time. Ideally suppliers ought to be fast in responding to their buyer's needs. However, in many cases, supplier slackness and laxity in responding to buyers needs has been a common occurrence characterized by increased lead times and cycle time. This has a negative impact to the buyers causing them to keep large buffer stock to cater for supplier uncertainty. Hence, it is paramount for firms to create relationships that boost the way suppliers respond to them. Hence, effective supply management and its strategies for creating competitiveness revolve around the on-time delivery of competitive quality goods and services, at a reasonable cost, involving the right business partners [34]. The sharing of information is a critical success factor if seamless product and money flows between initial suppliers and endconsumers in the 'macro' (or external) supply chain, as well as in the 'micro' (or internal) supply chain between different intra-organizational functions, is to be achieved. Inefficiency anywhere in the chain be it internal or external in nature will result in the chain as a whole failing to maximize its true competitive potential. The whole chain is only as strong as its weakest link. The most important problem encountered in both micro and macro supply chains, occurs when information about consumer demands becomes distorted on its way from the end-consumer to the initial supplier. A negative result of this information distortion is inaccurate demand forecasts and 
inefficient resource allocations, resulting in long lead times and high costs. Fast and accurate information sharing along all internal and external elements within a supply chain is a prerequisite for reducing this distortion [35]. [36] describe two types of integration: the first one involves the forward coordination of the physical product flow from the suppliers to the customers; the second one entails the backward coordination of the information flow from the customers to the suppliers. [37] identifies three levels of SCI: (a) manual SCI meaning human-tohuman information sharing (examples telephone, fax, e-mails); (b) semi-automated SCI meaning human-to-system information sharing (example web portals); and, (c) fully automated SCI meaning system-to-system information sharing (middleware systems). Companies in the supply chain are striving to increase control over their suppliers as well as to obtain up-to-date and accurate information about their business partners to enhance their supply chain competencies and agility.

The use of the Internet also facilitates e-sourcing, which is the process of finding new potential suppliers using ICT with the aim of decreasing search costs. Identifying new sources of suppliers increase competition during the tendering process. Organizations can also take advantage of virtual electronic purchasing consortia (EPC) to electronically conduct tasks that are necessary for the management of demand aggregation between two or more legal entities. EPC can exploit the potential of economies of scale and scope without the diseconomies of increased transaction and communication costs [38] and result in average net reductions in purchasing costs of over five per cent and a return on investment of over 70 per cent [39].

[40] carried out a study on the role of supplier management on procurement performance in manufacturing sector in Kenya: A Case of East African Breweries. This study therefore was aimed at evaluating the role of supplier management on procurement performance in manufacturing companies a case of East African breweries. The specific objectives covered supplier integration, supplier quality management, supplier collaboration and supplier training. The study findings indicated that $81 \%$ of change in procurement performance at EABL can be explained by four variables namely buyer supplier integration, Supplier quality management, Supplier collaboration, and Supplier Training. Supplier performance management is key to procurement performance as suppliers are integrated into organizations activities. EABL has a strong collaborative relationship with its suppliers and undertakes measures to train them. This has improved procurement performance to great extent (94.6\%). However, supplier integration and to be specific shared technology has not properly been achieved. The study recommended that EABL should focus more on integration and to maintain or improve on supplier collaboration and supplier training.

\subsubsection{Supply Chain Performance}

Every CEO must always be concerned with the competition. In today's economy the battlefield is shifting from individual company performance to Supply Chain Performance. Supply Chain Performance refers to the extended supply chain's activities in meeting end-customer requirements, including product availability, on-time delivery, and all the necessary inventory and capacity in the supply chain to deliver that performance in a responsive manner. Supply Chain Performance crosses company boundaries since it includes basic materials, components, subassemblies and finished products, and distribution through various channels to the end customer. It also crosses traditional functional organization lines such as procurement, manufacturing, distribution, marketing \& sales, and research \& development. To win in the new environment, supply chains need continuous improvement and to achieve this we need performance measures, or "metrics," which support global Supply Chain Performance improvements rather than narrow company-specific or function-specific (silo) metrics which inhibit chain-wide improvements [41] 
International Journal of Managing Value and Supply Chains (IJMVSC) Vol. 12, No. 2, June 2021

A procurement system is a vital component of a company's Supply Chain system. Typically, a company's procurement function is subdivided into strategic and operational processes since activities and priorities in these two areas are entirely different [42]. Supplier management, the pooling of purchase requisitions and procurement oriented product development are tasks that are typically assigned to strategic procurement. E-Procurement enables companies to decentralize operational procurement processes and centralize strategic procurement processes. This results to higher Supply Chain transparency provided by e-Procurement systems. Strategically, eProcurement will help to consolidate purchasing practices that will lead to greater discounts and better service from suppliers. It also accelerates the flow of important information between the buyer and supplier, reduces administrative hours thus freeing the workers to do other work. This allows the organization to respond quickly to highly competitive new market entrants and improve the chances of winning new business [43].

[44] states that to build up an integrated supply chain requires the management of material flow from three perspectives: strategic, tactical, and operational. From these perspectives, the use of systems, facilities, and people must be seen as a whole and work in a coordinated manner. $\mathrm{He}$ also mentions that a company can measure the supply chain performance by inventory level, service level, throughput efficiency, supplier performance and cost. [45] also stated that logistics play an important role in pursuing supply chain excellence which will lead to improved business performance. Another critical sub-factor of successful supply chain management is the analysis of the supplier market [46]. An important point according [47] is outsourcing, which is significant in the supply chain management for the opportunities and risks that it offers. Then, this factor comprises four sub-factors logistics, supplier markets, supplier performance, and materials sourcing.

\section{Methodology}

This study employed mixed research design by gathering both qualitative data. The Target population for this survey included all the 12 sugar companies in Kenya, both Public and private owned. Stratified random sampling was used to select a sample of 379 respondents. The main data collection instrument was open and closed ended questionnaires that were self-administered, interview guide and observation. Secondary sources of data were journals, conference reviews, books and magazine articles. Quantitative data was analyzed using descriptive statistical method. Regression analysis was applied to analyze the relationship between the dependent variable and independent variable. The results were fitted in the regression model, $\mathbf{Y}=\boldsymbol{\beta}_{\mathbf{0}}+\boldsymbol{\beta}_{\mathbf{1}} \mathbf{x}_{\mathbf{1}}+\boldsymbol{\varepsilon}$, Where: $\mathbf{Y}$ $=$ Supply chain performance (value of dependent variable), $\beta_{0}, \beta_{1}$ are the regression coefficients to be estimated, $\mathrm{X}_{1},=$ E-supplier management practice and $\varepsilon=$ error term.

\section{FINDINGS AND DISCUSSION}

\subsection{Results of Electronic Supplier Management Practice on Supply Chain Performance}

Respondents indicated E-supplier management practices highly enabled buyers and suppliers to develop a single shared forecast of demand and a plan of supply as evidenced by a mean 4.16. The study further found out that buyers were able to issue orders of materials to the suppliers in a streamlined manner (mean 4.08). It was found out that E-supplier management practice improved quick information sharing between buyers and suppliers (mean4.18). It was found out that Esupplier management practice significantly improved predictability of flow of goods (mean 4.03). It was further found out that electronic payment to suppliers improved delivery with the adoption of E-supplier management practice (mean 4.11). The study also established that E-supplier 
management practice improved relations with channel partners (mean 6.06) as presented by Table 1.1 .

This concurs to the study conducted by [48] on the effects of buyer/ supplier collaboration on eprocurement performance in state corporations in Kenya, found out that supplier collaboration enhances procurement performance hence creating a competitive advantage through sharing information making joint decision, inter-procurement relationship. This indicates that the level of supply chain collaboration has an important interaction effect on the relation between external resources and buying firm performance, where e-collaborative forms of buyer-supplier exchange facilitate greater access to external resources. This also concurs with the finding in the research, Relationship between E-procurement Adoption and Partnership Practice in Tea Firms, [49], that the electronic procurement adoption in tea firms has built partner relationships with suppliers, benefited in the reduction of cost, lead time and stable supply source and adopted the supply chain management practices. It has enhanced trust and partner relationship with suppliers using electronic procurement. The e-procurement adoption was found to make firm partner relationships improve supply chain performance.

Table 1. 1 Electronic supplier management practices

\begin{tabular}{lccc}
\hline \multicolumn{1}{c}{ Electronic supplier management practice } & & \\
\hline $\begin{array}{l}\text { Enables buyers and suppliers develop a single shared } \\
\text { forecast of demand and a plan of supply }\end{array}$ & 266 & 4.16 & 0.76 \\
$\begin{array}{l}\text { Buyers issue order of materials from the suppliers is } \\
\text { streamlined as a result of E-supplier management practice }\end{array}$ & 266 & 4.08 & 0.70 \\
$\begin{array}{l}\text { Has made possible quick information sharing between } \\
\text { buyers suppliers }\end{array}$ & 266 & 4.18 & 0.75 \\
$\begin{array}{l}\text { Has improved Predictability of flow of goods } \\
\begin{array}{l}\text { Electronic payment to suppliers improve delivery as a } \\
\text { result of E-supplier management practice }\end{array}\end{array}$ & 266 & 4.03 & 0.77 \\
$\begin{array}{l}\text { E-supplier management practice has improved relations } \\
\text { with channel partners }\end{array}$ & 266 & 4.11 & 0.87 \\
\hline
\end{tabular}

\subsection{Supply Chain Performance}

Respondents were asked to respond on supply chain performance statements and the findings indicate that the respondents agreed to a large extent that the application of E-supplier management practices reduces purchasing costs as indicated by a mean score of 4.43 . Further, it was their view that E-supplier management practices improved efficiency and time taken to complete procurement process with a mean of 4.52. It had enhanced standardized purchasing processes across the organization with a mean score of 4.31. It had resulted to reduced administrative cost with better effectiveness (mean 4.22). Respondents agreed that E-supplier management had improved effectiveness of SC processes (mean 4.24). It had resulted to reduced discretion and thus increased transparency (mean 4.27). It has enhanced SC mangers decision making (mean 4.18) and the E-supplier management practices had made possible reduced errors of order transmission to suppliers (mean 4.20). However, respondents also indicated that Esupplier management practices had slightly reduced procurement corruption and inventory levels as indicated by the mean score of 3.85 and 3.94 respectively. The results are indicated in table 1.2. The quantitative findings were supported by qualitative data by the $7(100 \%)$ managers interviewed that E-suppler improved efficiency of the supply chain because procurement process time reduced, reduced process costs by elimination of most stationery, that e-supplier 
management practices saves money by preventing duplicate spending, leveraging volume buying and that e-procurement saves the organization from needing more room and enhances file retrieval easy. On the issue of reports $6(85.7 \%)$ out of $7(14.3 \%)$ managers interviewed indicated that electronically conducting procurement makes it easier to write and analyze reports on procurement systems and this enables managers to make decisions based on supplier reports that are accessible electronically any time.

The finding of the quantitative and qualitative concurs with a research that the quest to improve service delivery is becoming an important agenda for most governments [50]; [51]; [52] and eprocurement has been introduced as a key strategic tool in increasing nations' competitiveness [53] and as a way to achieve better, more cost effective procurement systems, as well as greater transparency and accountability. Findings also concur with the study of [54], Influence of eprocurement implementation on supply chain performance in dairy industry in Kenya: a case of new KCC limited, that there is a positive correlation between dependent variable; supply chain performance and independent variables; ERP, E-order Processing, information sharing and Esupplier appraisal and the study concludes that ERP, E-order Processing, information sharing and E- supplier appraisal influences supply chain performance to a great extent.

Table 1.2 Supply chain performance

\begin{tabular}{lccc}
\hline E-supplier management practices & $\mathrm{N}$ & Mean & Std. Dev \\
\hline Reduces purchasing costs & 266 & 4.43 & 0.74 \\
Improves efficiency and time taken to complete procurement & 266 & 4.52 & 0.62 \\
process & 266 & 4.31 & 0.69 \\
Standardizes purchasing process across the organization & 266 & 4.22 & 0.80 \\
Reduces administrative cost with better effectiveness & 266 & 4.24 & 0.76 \\
Improves effectiveness of SC processes ( std process) & 266 & 4.27 & 0.83 \\
Reduces discretion \& increases transparency & 266 & 4.18 & 0.78 \\
Improves SC mangers decision making & 266 & 4.20 & 0.77 \\
Leads to reduction in errors of order transmission & 266 & 3.85 & 1.00 \\
Reduces procurement corruption & 266 & 3.94 & 1.01 \\
\hline Leads to reduction in inventory & & & \\
\hline
\end{tabular}

\subsection{Correlation Analysis for Electronic Supplier Management Practice}

There is a strong, positive correlation between supply chain performance and E-supplier management practice, which is statistically significant $(r=.478, n=266, p=.000)$. These findings indicate that there is a positive linear relationship between supply chain performance and E-supplier management practice. All the independent variables have a p-value of 0.000 implying that they have a significant positive effect on the Supply Chain performance of sugar firms. The Hypothesis postulated that,

Ho 4: E-supplier management practices has no significant influence on supply chain performance of sugar firms in Kenya.

The results of multiple regressions revealed that E-Supplier management practices have a beta value of $r=.478, p=.000$. Since the $\mathrm{p}$ - value is less than $<0.05$, the null hypothesis is rejected. It 
International Journal of Managing Value and Supply Chains (IJMVSC) Vol. 12, No. 2, June 2021

is then concluded that there is significant relationship between E-supplier management practices and supply chain performance as presented in table 1.3.

Table 1.3 Correlation for E-material management practice

\begin{tabular}{llcc}
\hline Variable & correlation & $\begin{array}{c}\text { Supply chain } \\
\text { performance }\end{array}$ & $\begin{array}{c}\text { E-Supplier mgt } \\
\text { practice }\end{array}$ \\
\hline Supply chain performance & Pearson correlation & 1 & $.478^{*}$ \\
& Sig. (2-tailed) & & .000 \\
& $\mathrm{~N}$ & 266 & 266 \\
E-Supplier mgt practice & Pearson correlation & $.478^{*}$ & 1 \\
& Sig. (2-tailed) & .000 & \\
& $\mathrm{~N}$ & 266 & 266 \\
\hline
\end{tabular}

**Correlation significant at the 0.01 level (2-tailed)

\subsection{Model Summary for Electronic Supplier Management Practices}

The model for the construct electronic supplier management was tested. The coefficient of determination and $\mathrm{R}=.0 .478 \mathrm{R}$ Square $=0.229$ at 0.05 at significance level. The coefficient of Determination (R2 Square) of 0.229 postulates that $22.9 \%$ of the procurement performance of the sugar growing and processing firms can be attributed to the electronic supplier management practices they have adopted in their procurement processes. This shows that there existed a positive correlation coefficient between E- supplier management and supply chain performance. The findings as indicated in table 1. 4 .

Table 1.4 Model summary E-supplier management practice

\begin{tabular}{llcccc}
\hline \multicolumn{7}{c}{ Model Summary } & & \\
\hline Model & $\mathrm{R}$ & $\begin{array}{c}\mathrm{R} \\
\text { Square }\end{array}$ & $\begin{array}{c}\text { Adjusted R } \\
\text { Square }\end{array}$ & $\begin{array}{c}\text { Std. Error of } \\
\text { the Estimate }\end{array}$ \\
\hline & 0.478 & 0.229 & 0.226 & 0.495 \\
\hline
\end{tabular}

Predictors: (Constant), E-supplier management

practice

\subsection{ANOVA for Electronic Supplier Management Practice}

The probability value of 0.000 indicates that the regression relationship is highly significant in predicting how E-supplier management affects supply chain performance of sugar firms. The $\mathrm{F}$ calculated at 5\% level of significance was 78.469 and since $\mathrm{F}$ calculated is greater than the $\mathrm{F}$ critical (value $=5.1922$ ), this shows that the overall model is significant as shown in table 1.5.

Table 1.5 ANOVA for E-supplier management practice

\begin{tabular}{|c|c|c|c|c|c|c|}
\hline Model & & $\begin{array}{c}\text { Sum of } \\
\text { Squares }\end{array}$ & $\mathrm{df}$ & $\begin{array}{c}\text { Mean } \\
\text { Square }\end{array}$ & $F$ & Sig. \\
\hline \multirow[t]{3}{*}{1} & Regression & 19.225 & 1 & \multirow{3}{*}{$\begin{array}{r}19.225 \\
.245\end{array}$} & \multirow[t]{3}{*}{78.469} & \multirow[t]{3}{*}{0.000} \\
\hline & Residual & 64.754 & 264 & & & \\
\hline & Total & 83.979 & 265 & & & \\
\hline
\end{tabular}




\subsection{Regression for Electronic Supplier Management Practice}

The regression equation is presented as follows; Supply chain Performance $=2.410+0.434$ (Esupplier management). The regression model has established that supply chain performance will equal to 2.410 when E- supplier management equal to zero. The finding also show that supply chain performance is predicted to improve by 0.434 when E-supplier management practices goes up by one unit. At $5 \%$ level of significance and $95 \%$ level of confidence, E-supplier management practice had p-value of 0.000 level of significance indicating that E-supplier management is statistically significant $(\mathrm{p}<0.05)$. The predictor (E-supplier management) has a low $p$-value hence it is likely to be a meaningful addition to the model because changes in the predictor's value are related to changes in the response variable. Table 1:6 provides the information of esupplier management.

Table 1.6 Regression for E-supplier management practice

\begin{tabular}{llllll}
\hline & $\begin{array}{l}\text { Unstandardized } \\
\text { Coefficients }\end{array}$ & $\begin{array}{l}\text { Std. } \\
\text { Error }\end{array}$ & $\begin{array}{l}\text { Standardized } \\
\text { Coefficients Beta }\end{array}$ & t & Sig. \\
\hline (Constant) & 2.410 & 0.203 & & 11843 & .000 \\
E-supplier management & 0.434 & 0.049 & 0.478 & 8.853 & .000 \\
\hline Dependent Variable: Supply chain performance & & & &
\end{tabular}

\section{SUMmary, CONCluSIONS AND RECOMMENDATIONS}

\subsection{Summary}

The study found out that E-supplier management practices enhances supply chain performance, majority $95.9 \%$ were of the view that E-supplier management enhances supply chain performance while $4.1 \%$ had a contrary view. To a large extent buyers and suppliers develop a single shared forecast of demand and a plan of supply, buyers issue order of materials from the suppliers is streamlined, quick information sharing with suppliers, predictability of flow of goods, electronic payment to suppliers improve delivery and improved relations with channel partners.

\subsection{Conclusion}

It is concluded that there is significant relationship between E-supplier practice and supply chain performance. Therefore, E-supplier management practices enhances supply chain performance as buyers and suppliers develop a single shared forecast of demand and a plan of supply, buyers issue order of materials from the suppliers is streamlined, quick information sharing with suppliers, predictability of flow of goods, electronic payment to suppliers improve delivery and improved relations with channel partners.

\subsection{Recommendations}

Two kinds of supply chain are proposed; Managerial and demand. Managerial where as a result of electronic supplier management practice, flow of goods and services from the suppliers are properly managed through information sharing between the buyer-seller thus improved deliveries. Demand supply chain where as a result of electronic supplier management practice, buyers and suppliers tend to develop a single shared forecast of demand and a plan of supply in the sense that buyers issue order for only needed materials from the suppliers and that suppliers fulfills the orders as requested by the buyers. 


\subsubsection{Managerial Recommendation}

It is recommended that management should ensure working Websites, working internal and External mail to improve supplier and buyers integration. To improve buyer/supplier relationship in time electronic payment to suppliers is necessary.

\subsubsection{Policy Recommendation}

The Government through the relevant ministry should institute policies concerning data handing to enhance the application of electronic procurement practices between the buyers and suppliers. This will improve the electronic payment, and use of electronic signature acceptance.

\section{REFERENCES}

[1]. Vaidya, A. Sajeev M and Callender G. (200). Critical factors that influence e-procurement implementation success in the public sector. Journal of public procurement, Volume 6, Issues $1 \& 3$, 70-99

[2]. McCue, C., \& Roman, A. V. (2012). "E-procurement: Myth or Reality?" Journal of Public Procurement, 12 (2): 212-238.

[3]. Brazel, J.F. and Dang, L. (2008) The Effect of ERP System Implementations on the Management of Earnings and Earnings Release Dates. Journal of Informationsystems, 22, 1-21. https://doi.org/10.2308/jis.2008.22.2.1

[4]. Levrat, E. and Lund, B. 2003).TELMA: A full e-maintenance Platform. Centre de Recherche en Automatique de Nancy (CRAN) - UMR 7039

[5]. Jessop B. (2006). Principal of Management, 8th Edition, Mc Graw Hill Publishing Company Ltd, New Dehli, India

[6]. Poirier, C. C. \& Bauer, M. J. (2000). E-Supply Chain - Using the Internet to Revolutionize your Business, Berrett-Koehler Publishers, San Francisco (CA).

[7]. Gitahi, L. (2011). "Exceptional Customer Relationship is the Key to Our Success" Nation Builder Newsletter.

[8]. Public Procurement Oversight Authority, (2014). Quarterly Bulletin. Issue No. 04, December 2014, Trends in Electronic Procurement in Kenya, Website: ppoa.go.ke, Retrieved 2014. wepoa.go.ke

[9]. Kenya National Assembly (2015), Report of the Departmental Committee on Agriculture, Livestock and Co-operatives on the Crisis Facing the Sugar Industry in Kenya

[10]. Kenya Sugar Directorate, (2017). Kenya sugar industry Report

[11]. Narasimhan, R., Kim, S. W., 2002. Effect of supply chain integration on the relationship between diversification and performance: evidence from Japanese and Korean firms. Journal of Operations Management 20, 303-323.

[12]. Lynch et al., 2000,J.W. Lynch, G.D. Smith, G.A. Kaplan, J.S. House, Income inequality and mortality: Importance to health of individual income, psychosocial environment, or material conditions British Medical Journal, 320 (2000), pp. 1200-120

[13]. McKone-Sweet, K., \& Lee, Y. T. (2009). Development and analysis of a supply chain strategy taxonomy. Journal of Supply Chain Management, 45(3), 3-24

[14]. Flynn, B. B., Huo, B. and Zhao, X. (2010). The Impact of Supply Chain Integration on Performance: A Contingency and Configuration Approach. Journal of Operations Management. 28: 58-71.

[15]. Dyer, J.H. and Singh, H. (1998) The Relational View: Cooperative Strategy and Sources of Interorganizational Competitive Advantage. Academy of Management Review, 23, 660-679

[16]. Hitt, M. A., Nixon, R. D., Clifford, P. G. and Coyne, K. (1999). The Development and Use of Strategic Resources. In Hitt, M. A., Clifford, P. G., Nixon, R. D. and Coyne, K. P. (Eds.) Dynamic Strategic Resources: Development, Diffusion, and Integration (pp. 1-15). New York: Wiley.

[17]. Pagell, M. and Krause, D.R. (2004). Re-exploring the relationship between flexibility and the external environment. Journal of Operations Management, 21, 629-649.doi:10.1016/j.jom.2003.11.00

[18]. Narasimhan, R., Kim, S. W., 2002. Effect of supply chain integration on the relationship between diversification and performance: evidence from Japanese and Korean firms. Journal of Operations Management 20, 303-323. 
International Journal of Managing Value and Supply Chains (IJMVSC) Vol. 12, No. 2, June 2021

[19]. Lambert, D., \& Lines, D. (2000). Understanding Assessment. London: Routledge Falmer.

[20]. Pagell, M. and Krause, D.R. (2004). Re-exploring the relationship between flexibility and the external environment. Journal of Operations Management, 21, 629-649.doi:10.1016/j.jom.2003.11.00

[21]. Kwon, I.W.G. and Suh, T. (2004) Factors Affecting the Level of Trust and Commitment in Supply Chain Relationship. The Journal of Supply Chain Management, No. 7.

[22]. Narasimhan, R., Kim, S. W., 2002. Effect of supply chain integration on the relationship between diversification and performance: evidence from Japanese and Korean firms. Journal of Operations Management 20, 303-323.

[23]. Flynn, B. B., Huo, B. and Zhao, X. (2010). The Impact of Supply Chain Integration on Performance: A Contingency and Configuration Approach. Journal of Operations Management. 28: 58-71

[24]. Simchi-Levi, D., Kaminsky, P \&Simchi-Levi, E. (2010). Designing and Managing the Supply Chain: Concepts, Strategies, and Case Studies. Boston, MA: McGraw-Hill.

[25]. Chopra S, Meindl P, Kalra D (2010). Supply chain management. Pearson Education, Noida.

[26]. Wachiuri, Waiganjo \& Oballa, (2015). „Role of supplier development on procurement performance of manufacturing industry in Kenya ${ }^{\text {eee }}$ international journal of education and research, 3(3) 2201-633

[27]. Simichi-Levi, D., Kaminisky, P., Simichi-Levi, E., (2009)."Designing and Managing the Supply Chain", McGraw-Hill, Boston

[28]. Humphrey, J. and Schmitz, H. (2000) Governance and Upgrading: Linking Industrial Cluster and Global Value Chain Research, IDS Working Paper 120, Brighton: IDS

[29]. Tim F. Into the depths of the I-E-I framework: using the internet to create value in supply chain, 2014.

[30]. Turner, R.K. and Bateman, I.J. (1993) Valuation of the environment, methods and techniques: The contingent valuation method, in Turner R.K. (ed.) Sustainable Environmental Economics and Management: Principles and Practice, Belhaven Press, London, pp120-191

[31]. Li S. (2002), An Integrated Model for Supply Chain Management Practice, Performance and Competitive Advantage. In: Manufacturing Management, Ohio: The University of Toledo. 1-266

[32]. Li S. (2002), An Integrated Model for Supply Chain Management Practice, Performance and Competitive Advantage. In: Manufacturing Management, Ohio: The University of Toledo. 1-266

[33]. Bowersox DJ, Closs DJ, \& Cooper MB. (2007). Supply Chain Logistics Management. New York.

[34]. Wachiuri, Waiganjo \& Oballa, (2015). „Role of supplier development on procurement performance of manufacturing industry in Kenya ${ }^{\text {eeee }}$ international journal of education and research, 3(3) 2201-633

[35]. Nurmilaakso, J. M. (2008). Adoption of e-business functions and migration from EDIbased to XMLbased e-business frameworks in supply chain integration. International Journal of Production Economics, 113(2), 721733. doi:10.1016/j.ijpe.2007.11.001

[36]. Monczka, R., Trent, R., \& Handfield, R. (1998). Purchasing and supply chain management. Cincinnati: South Western College Publishing.

[37]. Nurmilaakso, J. M. (2008). Adoption of e-business functions and migration from EDIbased to XMLbased e-business frameworks in supply chain integration. International Journal of Production Economics, 113(2), 721733. doi:10.1016/j.ijpe.2007.11.001

[38]. Corsten, D., \& Zagler, M. (1999). Purchasing consortia and Internet technology. In A. Erridge (ed.) Perspectives on Purchasing and Supply for the Millennium, 8th International Annual IPSERA Conference (pp. 139-147) Belfast: University of Ulster

[39]. Huber, B., Sweeney, E., \& Smyth, A. (2004). Purchasing consortia and electronic markets - a procurement direction in integrated supply chain management'. International Journal of Electronic Markets, 14(4), 284-294. doi:10.1080/10196780412331311739

[40]. Kepher A., Shalle I. \& Oduma E. (2015). Role of Supplier Management on Procurement Performance in Manufacturing Sector in Kenya: A Case of East African Breweries, Kenya. International Journal of Social Science and Humanities Research ISSN 2348-3164～(online) Vol. 3, Issue 4, pp: (540555).

[41]. Hausman W.H. (2017), Supply Chain Performance Metrics. In: The Practice of Supply Chain Management: Where Theory and Application Converge. International Series in Operations Research \& Management Science, vol 62. Springer, 2017, Boston, MA

[42]. Turban, E. and Gehrke, D. (2000) Determinants of E-Commerce Website. Human Systems Management, 19, 111-120.

[43]. Egbu C. Vines M. and Tookey J. (2004). The Role of Knowledge Management in E-Procurement nitiatives for Construction Organisations, Proceedings of ARCOM Twentieth Annual Conference 
International Journal of Managing Value and Supply Chains (IJMVSC) Vol. 12, No. 2, June 2021

2004, September 1-3, Heriot Watt University, (Khosrowshami,F Editor), Vol. 1, Arcom, University of Reading, Reading, $661-671$.

[43]. Ebgu, C O (2004) Managing knowledge and intellectual capital for improved organizational innovations in the construction industry: an examination of critical success factors. Construction and Architectural Management, 11(5), 301 - 315.

[44]. Stevens, C.G. (1989) "Integrating the Supply Chain". International Journal of Physical Distribution \& Logistics Management, Vol.19 No. 8, pp.3 - 8.

[45]. Lear-Olimpi M., (1999). Get in step for the future. Warehousing Management (1999) 6:15.

[46]. Preker, Alexander S.; Liu, Xingzhu; Velenyi, Edit V.; Baris, Enis. 2007. Public Ends, Private Means : Strategic Purchasing of Health Services. Washington, DC: World Bank. (C) World Bank. https://openknowledge.worldbank.org/handle/10986/6683

[47]. Canbolat, Gupta, Matera and Chelst (2008). Analysing Risk in Sourcing Design and Manufacture of Components and Sub-Systems to Emerging Markets. International Journal of Production Research 46(18):5145-5164

[48].Shalle, Guyo, \& Amuhaya, (2014). Effects of Buyer/Supplier Collaboration on E-Procurement Performance in State Corporations in Kenya, European Journal of Management Sciences and Economics, 1(4), 170-185

[49]. Chirchir, E. (2015). Relationship between E-procurement Adoption and Partnership Practice in Tea Firms, The International Journal of Business and Management, 8.

[50]. Kaliannan, M., Awang, H. and Raman, M. (2009) 'Electronic procurement: a case study of Malaysia's e-perolehan (e-procurement) initiative', International Journal of Electronic Governance, Vol. 2, Nos. 2-3, pp.103-117

[51]. Vaidya K. \& Hyde M., (2011). Inter-organisational information systems assimilation: An empirical evaluation in light of the diffusion of innovation theory. International Journal of Business Information Systems 7(3):247-268

[52]. Basheka, B., Oluka, P. \& Mugurusi, G. (2012). Adopting new approaches for public procurement efficiency: critical success factors (CSFs) for the implementation of e-procurement in Uganda's public sector, International Journal of Procurement Management, 5(6), 712-732.

[53]. Basheka, B., Oluka, P. \& Mugurusi, G. (2012). Adopting new approaches for public procurement efficiency: critical success factors (CSFs) for the implementation of e-procurement in Uganda's public sector, International Journal of Procurement Management, 5(6), 712-732.

[54]. Nyagah, K. \& Patrick, M. (2015). Influence of e-procurement implementation on supply chain performance in dairy industry in Kenya: a case of new KCC limited. International Journal of Innovative Social Sciences \& Humanities Research, 3(2), 31-4. 